\title{
Biochemical and histopathological studies on patients with mucopolysaccharidoses, two of whom had been treated by fibroblast transplantation
}

\author{
JULIE CROW,${ }^{*}$ DOROTHY A GIBBS,$\dagger$ WENDY COZENS, $\dagger$ ELIZABETH SPELLACY,$\dagger$ \\ RWE WATTS $\dagger$
}

From the $†$ Division of Inherited Metabolic Diseases, MRC Clinical Research Centre, and the ${ }^{*}$ Department of Histopathology, Northwick Park Hospital, Watford Road, Harrow, Middlesex

SUMMARY Biochemical and pathological observations on tissues from two patients with Hurler disease (mucopolysaccharidosis IH; $\alpha$-L-iduronidase deficiency) who had been treated by fibroblast transplants as a means of enzyme replacement treatment are reported.

These results and those obtained in three surgical specimens [ligamentum flavum with dura mater from a case of Scheie disease (mucopolysaccharidosis IS; $\alpha$-L-iduronidase deficiency); a fetus with Hurler disease; and tonsil from a patient with Hunter disease (mucopolysaccharidosis II; $\alpha$-L-idurono-2-sulphate sulphatase deficiency)] illustrate the inadequacy of routine histological processing to demonstrate the abnormal glycosaminoglycan accumulation in this group of diseases. A combined approach using histochemistry and electron microscopy enables the extent of both extracellular and intracellular involvement to be assessed. The fetus (20 wk gestation) already showed evidence of Hurler disease.

The pathological appearances in both of the fibroblast-transplanted patients were those which would have been expected in patients dying with unmodified Hurler disease. There was no detectable $\alpha$-L-iduronidase activity in the brain, liver, kidney or in fibroblasts cultured from either the transplantation sites or from remote subcutaneous sites in either of the transplanted patients.

These results are discussed from the viewpoint of their bearing on the pathophysiology of the mucopolysaccharidoses and proposals for their treatment by enzyme replacement.

The mucopolysaccharidoses (MPS) are a group of lysosomal storage diseases each of which is due to an inherited deficiency of a glycosaminoglycan*degrading enzyme (Table 1). Dean and his colleagues proposed the subcutaneous transplantation of cultured fibroblasts as a means of long-term enzyme replacement in these diseases on the basis of short-term studies in two patients with Hunter dis-

\footnotetext{
* The term mucopolysaccharide is unsatisfactory because it can lead to confusion between polysaccharides containing both hexosamines and hexuronic acids and related substances which do not contain hexuronic acids. The term glycosaminoglycuronans ${ }^{7}$ is also unsatisfactory in relation to the mucopolysaccharidoses because this excludes keratan sulphate, which contains galactose instead of hexuronic acid residues. The term glycosaminoglycan is used generically for hyaluronic acid, chondroitin and its sulphates (4- and 6-), dermatan and heparan sulphates, keratan sulphate and heparin.
}

Accepted for publication 7 October 1982 ease (MPS II) ${ }^{34}$ These workers subsequently reported a similar study in Sanfilippo-A disease (MPS IIIA). ${ }^{5}$ However, a prospective clinical trial in a group of nine patients, which included cases of Hurler disease (MPS IH), Hunter disease (MPS II) and Sanfilippo-B disease (MPS IIIB), produced no long-term clinical benefit or consistent biochemical changes. ${ }^{\circ}$

This paper reports the results of enzyme assays on selected tissues from two treated patients who died during the transplantation programme ${ }^{6}$ and on fibroblasts grown from subcutaneous tissue removed from the transplantation site at postmortem.

Although vacuolated cells can be demonstrated by light microscopy and distended lysosomes by electron microscopy in this group of diseases the water solubility of the glycosaminoglycans (GAGS) makes it difficult to demonstrate them histochemi- 
Table 1 The mucopolysaccharidoses

\begin{tabular}{|c|c|c|c|c|c|}
\hline Identification & Eponym & Enzyme deficiency & $\begin{array}{l}\text { Excreted } \\
\text { glycosaminoglycans }\end{array}$ & Inheritance & Organs mainly affeeted \\
\hline $\mathrm{IH}^{*}$ & Hurler & $\alpha$-L-iduronidase & $\begin{array}{l}\text { Dermatan sulphate } \\
\text { Heparan sulphate }\end{array}$ & Autosomal recessive & $\begin{array}{l}\text { Central nervous sy践; } \\
\text { skeleton; viscerao }\end{array}$ \\
\hline IS $\dagger$ & Scheie & $\alpha$-L-iduronidase & $\begin{array}{l}\text { Dermatan sulphate } \\
\text { Heparan sulphate }\end{array}$ & Autosomal recessive & $\begin{array}{l}\text { Skeleton (mild relative } \\
\text { to Hurler) } \\
\text { Viscera (mild relati退 to } \\
\text { Hurler) }\end{array}$ \\
\hline $\mathrm{IH} / \mathrm{S}$ & Hurler/Scheie & $\alpha$-L-iduronidase & $\begin{array}{l}\text { Dermatan sulphate } \\
\text { Heparan sulphate }\end{array}$ & Autosomal recessive & $\begin{array}{l}\text { Phenotype intermefiate } \\
\text { between Hurler and } \\
\text { Scheie }\end{array}$ \\
\hline II $^{*}$ & Hunter & $\begin{array}{l}\alpha \text {-L-idurono-2-sulphate } \\
\text { sulphatase }\end{array}$ & $\begin{array}{l}\text { Dermatan sulphate } \\
\text { Heparan sulphate }\end{array}$ & Sex linked recessive & $\begin{array}{l}\text { Central nervous systepm; } \\
\text { skeleton; viscerac }\end{array}$ \\
\hline $\begin{array}{l}\text { IIIA } \\
\text { IIIB }\end{array}$ & $\begin{array}{l}\text { Sanfilippo-A } \\
\text { Sanfilippo-B }\end{array}$ & $\begin{array}{l}\text { Heparan N-sulphatase } \\
\text { N-acetyl- } \alpha \text {-D-glucosaminidase }\end{array}$ & Heparan sulphate & Autosomal recessive & Central nervous syझtem \\
\hline IIIC & Sanfilippo-C & $\begin{array}{l}\alpha \text {-glucosamine- } \mathrm{N} \text {-acetyl } \\
\text { transferase }\end{array}$ & Heparan sulphate & Autosomal recessive & Central nervous syș \\
\hline IIID $\ddagger$ & Sanfilippo-D & $\begin{array}{l}\mathrm{N} \text {-acetyl-glucosamine-6-sulphate } \\
\text { sulphatase }\end{array}$ & Heparan sulphate & Not established & Central nervous sysem \\
\hline IVA & Morquio A & $\begin{array}{l}\text { Galactosamine 6-sulphate } \\
\text { sulphatase }\end{array}$ & Keratan sulphate & Autosomal recessive & Skeleton \\
\hline $\begin{array}{l}\text { IVB } \\
\text { VI }\end{array}$ & $\begin{array}{l}\text { Morquio B } \\
\text { Maroteaux-Lamy }\end{array}$ & $\begin{array}{l}\beta \text {-galactosidase } \\
\mathrm{N} \text {-acetylgalactosamine } \\
\text { 4-sulphatase }\end{array}$ & $\begin{array}{l}\text { Keratan sulphate } \\
\text { Dermatan sulphate }\end{array}$ & $\begin{array}{l}\text { Autosomal recessive } \\
\text { Autosomal recessive }\end{array}$ & $\begin{array}{l}\text { Skeleton } \\
\text { Skeleton }\end{array}$ \\
\hline VII & Sly & $\beta$-glucuronidase & $\begin{array}{l}\text { Dermatan sulphate } \\
\text { Heparan sulphate }\end{array}$ & Autosomal recessive & Central nervous system \\
\hline
\end{tabular}

*Both formerly called gargoylism because of the characteristic and similar facies which is also seen in chondroitin 6-sulphaturia, the mucolipidoses (typts I, II and III) and in some cases of $\alpha$-fucosidosis and mannosidosis ${ }^{1}$ tScheie disease was originally classified as mucopolysaccharidosis V. It was reclassified as mucopolysaccharidosis IS when the defective enzyme was shown
to be $\alpha$-L-iduronidase. Hurler and Scheie diseases are presumably due to allelic mutations at the same gene locus. The intermediate Hurler/Scheie phenotype may be due to either a third allelic mutation or double heterozygosity for mutations which cause Hurler and Scheie diseases.

$¥$ This variant was described by Kresse and his colleagues. ${ }^{2}$

cally. It was important from the viewpoint of the clinical trial to be able to study the distribution of mucopolysaccharides in the tissues of the two patients who died. The use of a new technique for detecting metachromasia and electron microscopy to confirm the presence of distended vacuoles has enabled us to make useful clinicopathological correlations. We have also shown the value of this approach by our findings in several surgical specimens [ligamentum flavum and dura mater from a patient with Scheie disease (MPS IS), tonsil from a case of Hunter disease and a fetus with Hurler disease].

\section{Patients and methods}

\section{PATIENTS}

The clinical findings and the course of the disease in patients 1,2 , and 4 , and the brain computed tomography appearances have been reported. ${ }^{69}$

\section{Patient 1 [Patient $1^{6}$ Patient $A^{10}$ ]}

Patient 1 was referred at 5 yr 6 months and was transplanted six times between the ages of 5 yr 11 months and 9 yr 6 months. Most of the physical signs of Hurler disease were present when she was referred except that her intellectual functions were unusually well preserved with comprehension being approximately appropriate to her age.

All of the physical components of the Hurler disease phenotype progressed. She developed an acute severely symptomatic hydrocephalus for which a ventriculoatrial shunt was inserted, acute glaucoma requiring trabeculectomy, a combination of sensorineural and conductive deafness which was helped by hearing aids, and bilateral median nerve compression in the carpal tunnels which was relieved surgically. Instability at the hip joints finally made the patient chair-bound. She died at 9 yr 8 months of age. In spite of her multiple severe physical handicaps and interrupted formal education, the results of tests of intellectual function were only about two years behind her chronological age at 9 yr 2 months old. She had insight into her condition and showed an appropriate depressive psychological reaction.

At necropsy, the external appearances and gross anatomical findings were typical of advanced Hurler disease except that the brain appeared grossly normal and the Spitz-Holzer valve was in place. The meninges were diffusely thickened but no arachnoid cysts were found, and there were no gross abnormalities specifically related to the region of the arachnoid granulations. The heart weighed $120 \mathrm{~g}$ and showed thickening of all the valve cusps, the 
chordae tendinae, and the walls of the coronary arteries.

\section{Patient 2 [Patient $3^{6}$ Patient $\left.E^{10}\right]$}

Patient 2 was referred at 4 yr 11 months with most of the phenotypic features of Hurler disease being present, the diagnosis having been made when she was 2 yr old. She was transplanted at 5 yr 1 month, 6 yr 3 months and 6 yr 11 months. She was at about the $2 \mathrm{yr}$ level of psychomotor development when referred but regressed from even this level of attainment as the disease followed the classical progressive course. A cardiac systolic murmur was audible at the left sternal edge during the last two and a half years of the patient's life. Its intensity had gradually increased to grade $3 / 6$ and echocardiograms at 7 yr 0 months and 7 yr 9 months had shown the appearances of hypertrophic cardiomyopathy. She died at home from respiratory failure, aged $8 \mathrm{yr}$ 6 months, the clinical history suggesting a medullary pressure cone associated with gross hydrocephalus.

The external appearances and gross anatomical findings at necropsy were typical of advanced Hurler disease. In contrast to patient 1 the ventricles of the brain were grossly dilated. The meninges at the base of the skull and over the cervical cord were markedly thickened, but there were no arachnoid cysts or abnormalities in the region of the arachnoid granulations. The heart weighed $105 \mathrm{~g}$, the wall of the left ventricle and the interventricular septum were thickened and there was concentric thickening of the right coronary artery. The valves appeared grossly normal.

\section{Patient 3 [Patient $10^{9}$ ]}

Patient 3 was a 21-year-old man who had Scheie disease diagnosed on clinical and enzymological grounds. The presenting symptoms had been stiffness of the hands and an abnormal gait at $4 \mathrm{yr}$ of age. The joint stiffness had progressed so that the range of movements in all his joints was very limited and he could only walk about $20 \mathrm{~m}$. He was $1.43 \mathrm{~m}$ tall, weighed $35.5 \mathrm{~kg}$ and had heavy features without a specifically Hurler-like facies. There was corneal clouding, micrognathia, cardiac systolic and diastolic murmurs (the echocardiogram suggested mild aortic stenosis) and hepatosplenomegaly. He had also had attacks of severe sleep apnoea necessitating a tracheostomy. The results of pulmonary function tests indicated a severe restrictive defect. The patient had signs of spinal cord compression at the $\mathrm{C}_{5}-\mathrm{C}_{6}$ level and of bilateral median nerve compression in the carpal tunnels. Computed tomography (CT) and myelography confirmed the spinal cord compression. ${ }^{7}$ The median nerve and spinal cord compressions were relieved surgically. The patient's physical capabilities increased greatly after these operations and a regimen of rigorous physiotherapy. The ligamentum flavum and dura mater removed during the cervical laminectomy were examined in this study.

\section{Patient 4 [Patient $7^{9}$ and Patient $8^{6}$ ]}

Patient 4 had Hunter disease. He developed gross nasopharyngeal obstruction due to enlarged tonsils and adenoids. These were removed when he was 4 yr 4 months old and the tonsillar tissue examined in the present work.

\section{Hurler disease fetus}

This fetus was the product of the third pregnancy of the mother of patient 2 . Amniocentesis was performed at the sixteenth week of pregnancy. Amniotic cells were cultured ${ }^{11}$ and the $\alpha$-L-iduronidase activity was measured ${ }^{12}$ on cultures grown for 10 days after trypsinisation. The amniotic cells had no detectable $\alpha$-L-iduronidase activity (reference extreme range $209-1070 \mathrm{nmol} / \mathrm{mg}$ protein $/ 18 \mathrm{~h}$, mean 570 SEM 119, $\mathrm{n}=23$ determinations on 18 subjects). The pregnancy was terminated after about 20 wk gestation. The fetus was somewhat macerated but there were no gross congenital abnormalities or visible stigmata of Hurler disease. The diagnosis was confirmed on fibroblasts cultured from the fetus. Control necropsy tissues for the biochemical assays were obtained from four adult patients.

\section{METHODS}

\section{Biochemical}

Fibroblast cultures Fibroblasts from skin biopsies were grown in Ham's F10 medium as described previously. ${ }^{10}$ Skin biopsies were taken at postmortem with the same sterile technique as that used during life.

Cross correction studies In the case of the patients who were treated by fibroblast transplantation, we showed that each donor's cells could correct the metabolic lesion in the corresponding patient's cells by correcting the excessive incorporation of ${ }^{35} \mathrm{~S}$ labelled glycosaminoglycans when the patient's cells were growing in tissue culture medium in which the donor's fibroblasts had been grown ${ }^{12}$ (with minor modifications. ${ }^{13}$ ). A typical example is shown in Fig. 1.

Enzyme assays The necropsy tissues were immediately chilled on ice, cut into portions (approximately $5 \mathrm{~cm}^{3}$ ) each of which was packed in a separate plastic bag and duplicate sets were stored at $-70^{\circ} \mathrm{C}$ and at $-30^{\circ} \mathrm{C}$ respectively. The necropsies on patients 1 and 2 were begun about $30 \mathrm{~min}$ and $4 \mathrm{~h}$ after death respectively and the organs required for biochemical 


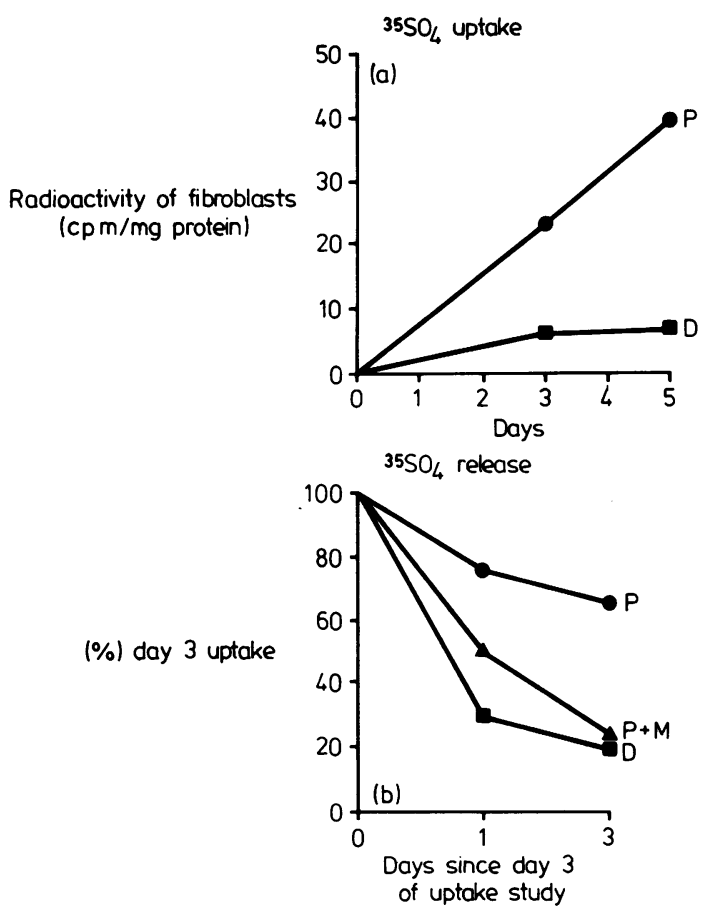

Fig. 1 The uptake and release of ${ }^{35} S$-labelled inorganic sulphate by fibroblasts from patient 2 showing the characteristic continuous uptake and limited release of isotope. The correction of these abnormal findings by growing the cells in tissue culture medium in which the donors fibroblasts had previously been grown is also shown. The terms "uptake" and "release" parts of the test refer to the initial period of culture in the presence of ${ }^{35} S$-labelled inorganic sulphate and the further period of culture when this has been replaced by unlabelled inorganic sulphate. ${ }^{12} 13$ $P=$ Patient's cells grown in unconditioned tissue culture medium. $D=$ donor's cells grown in unconditioned tissue culture medium. $P+D M=$ Patient's cells grown in tissue culture medium previously conditioned by having had the donor's cells grown in it

and ultrastructural studies removed as rapidly as possible. Control necropsy tissues were stored in the same way and for similar periods of time.

$\alpha$-L-iduronidase (EC 3.2.1.76) was measured spectrophotometrically in fibroblasts and leucocytes with phenyliduronide as substrate, ${ }^{12} 14$ and spectrophotofluorimetrically in necropsy tissues with 4-methyl-umbelliferyliduronide as the substrate. ${ }^{615}$

The specific assay conditions to permit the calculation of absolute reaction rates were established for each of the necropsy tissues (liver, kidney, and brain) and it was shown that the 4-methylumbelliferone release was linear with time beyond the duration of the incubation and beyond the largest amount of enzyme, measured as tissue protein, added to the assay system. Incubations lasting $18 \mathrm{~h}$ were also used in order to exclude the presence of very low activities which might not have been apparrent after the standard one or two-hour incubation, although the reaction does not follow a linear time course for the whole of this period.

Liver tissue (about $0.5 \mathrm{~g}$ ) was homogenised in 2.0 $\mathrm{ml}$ of Triton X-100 $(1 \mathrm{~g} / \mathrm{l})$ and the homogenate diluted tenfold with the Triton $\mathrm{X}-100$ solution. The reaction mixture consisted of dilute homogenate (25 $\mu \mathrm{l}$, approximately $5 \mu \mathrm{g}$ protein) and 4methylumbelliferyliduronide [ $25 \mu \mathrm{l}, 50 \mu \mathrm{mol}$, in formate buffer $(0.5 \mathrm{M}, \mathrm{pH} 3.5)]$. The solutions were mixed after warming to $27^{\circ} \mathrm{C}$, incubated at this temperature for either $1 \mathrm{~h}$ or $18 \mathrm{~h}$, and the reaction stopped by adding glycine buffer $(200 \mu \mathrm{l}), 0.5 \mathrm{M}$, $\mathrm{pH} 10 \cdot 4)$. Reagent blanks were prepared by incubating the homogenate $(25 \mu \mathrm{l})$, adding the glycine buffer followed by a separately incubated portion $(25$ $\mu l)$ of the substrate solution. A calibration curve for the fluorescence intensity of 4-methylumbelliferone was constructed in duplicate with each batch of assays. The fluorescence was read against a blank containing water in place of 4-methylumbelliferone solution. The excitation and emission wavelengths were $360 \mathrm{~nm}$ and $448 \mathrm{~nm}$ respectively.

The kidney tissue was homogenised as described for the liver and the homogenate diluted sevenfold with the Triton $\mathrm{X}-100$ solution. The reaction mixture and assay conditions were as described for liver except that the $25 \mu \mathrm{l}$ portion of the diluted homogenate contained 60-70 $\mu \mathrm{g}$ protein and the shorter incubation period was two hours.

The assay on brain tissue was as described for the kidney except that the concentrated homogenate was diluted sixfold, this again gave $60-70 \mu \mathrm{g}$ protein in each $25 \mu \mathrm{l}$ portion of the diluted homogenate. $\beta$-galactosidase (EC 3.2.1.23) was determined as described previously. ${ }^{14}$

$\alpha$-L-idurono-2-sulphate sulphatase was determined as described by Dean and colleagues. ${ }^{4}$

Lactate dehydrogenase (EC 1.1.1.27) was determined with pyruvate substrate. ${ }^{10}$

Protein was determined colorimetrically. ${ }^{17}$

Urinary glycosaminoglycans All of the patients were shown to be excreting abnormal amounts of glycosaminoglycans. ${ }^{18}$ Thin layer chromatography ${ }^{19}$ showed these to be dermatan and heparan sulphates.

\section{Microscopy}

Histology Paraffin wax sections were made of the surgical specimens and of representative tissues 
from the necropsies, these were then stained with either haematoxylin and eosin or azure A.

Histochemistry Selected tissues were placed on paper rolls dampened with phosphate-buffered saline and snap-frozen in isopentane cooled by liquid nitrogen. These blocks were transported in crushed solid $\mathrm{CO}_{2}$ and stored at $-70^{\circ} \mathrm{C}$. Cryostat sections (15-20 $\mu \mathrm{m}$ thick) were cut, picked up on slides and immediately placed in absolute ethanol saturated with azure $A$ for $10 \mathrm{~min}$. They were then transferred to $70 \%$ ethanol saturated with azure A for 5-10 min, dehydrated rapidly in absolute ethanol, cleared in xylene and mounted in a resinous medium [modified from Dorling ${ }^{20}$ ]. Control sections were pretreated with $10 \%$ formol saline for $10 \mathrm{~min}$, rinsed in tap water and transferred through $70 \%$, $90 \%$ and absolute ethanol before being treated as above.

The distribution of metachromasia was noted and its degree scored on a scale of $(-$ to ++++$)$.

Electron microscopy If no orientation was necessary, the tissue was chopped into cubes $1 \mathrm{~mm}^{3}$ and fixed in $3 \%$ glutaraldehyde in cacodylate buffer $(0 \cdot 1 \mathrm{M})$. In the case of the skin and eyes, somewhat larger blocks were necessary in order to maintain orientation. Postfixation was carried out with $1 \%$ osmium tetroxide and block-staining with $1 \%$ aqueous uranyl acetate. Dehydration was performed through graded acetones to propylene oxide and the blocks were embedded in Spurr resin. One micrometre sections were stained with toluidine blue. Ultrathin sections were collected on to copper grids, stained with Reynold's lead citrate and carbon coated before being viewed in a Philips 300 electron microscope.

An attempt was made to assess the degree of involvement of the cells by scoring on a scale of (to ++++ ).

Examination of the eyes In patients 1 and 2, the eyes were available for examination. In patient 2 , one eye was dissected at the time of the necropsy and blocks were taken for both snap-freezing and electron microscopical examination. The second eye was fixed by injection and immersion in buffered

Table $2 \alpha$-L-iduronidase, $\beta$-galactosidase and lactate dehydrogenase activity of liver and kidney (the temperatures quoted are those at which the tissue was stored)

\begin{tabular}{|c|c|c|c|c|c|}
\hline \multirow[t]{3}{*}{ Subject } & \multirow[t]{3}{*}{$\operatorname{Temp}\left({ }^{\circ} \mathrm{C}\right)$} & \multicolumn{4}{|l|}{ Liver } \\
\hline & & \multicolumn{2}{|c|}{$\begin{array}{l}\alpha \text {-L-iduronidase } \\
\text { (nmol/mg protein) }\end{array}$} & \multirow[t]{2}{*}{$\begin{array}{l}\text { B-galactosidase } \\
\text { (nmol/mg protein/h) }\end{array}$} & \multirow[t]{2}{*}{$\begin{array}{l}\text { Lactate dehydrogenase } \\
\text { (nmol NADH } / \mathrm{mg} \text { protein } / \mathrm{min})\end{array}$} \\
\hline & & Per hour & Per 18 hours & & \\
\hline \multirow[t]{2}{*}{ Patient 1} & -30 & ND & ND & ND & ND \\
\hline & -70 & 0 & & $22 \cdot 6$ & 151 \\
\hline \multirow[t]{2}{*}{ Patient 2} & -30 & 0 & 0 & $5 \cdot 8$ & 91.7 \\
\hline & -70 & 0 & 0 & $4 \cdot 7$ & $78 \cdot 1$ \\
\hline \multirow{2}{*}{ Control 1} & -30 & $1 \cdot 5$ & 9.4 & 682 & 171 \\
\hline & -70 & $1 \cdot 6$ & $16 \cdot 7$ & 443 & 143 \\
\hline Control 2 & $\begin{array}{l}-30 \\
-70\end{array}$ & $2 \cdot 1$ & $11 \cdot 2$ & $\begin{array}{l}274 \\
278\end{array}$ & 112 \\
\hline \multirow{2}{*}{ Control 3} & -30 & $\begin{array}{l}2 \cdot 1 \\
1 \cdot 9\end{array}$ & $\begin{array}{l}16 \cdot 7 \\
11.8\end{array}$ & $\begin{array}{l}278 \\
586\end{array}$ & $\begin{array}{l}123 \\
145\end{array}$ \\
\hline & -70 & 1.8 & $12 \cdot 5$ & 537 & 119 \\
\hline \multirow[t]{2}{*}{ Control 4} & -30 & $2 \cdot 2$ & $11 \cdot 6$ & 264 & 129 \\
\hline & -70 & $1 \cdot 7$ & $14 \cdot 8$ & 228 & 124 \\
\hline \multirow[t]{3}{*}{ Subject } & $\operatorname{Temp}\left({ }^{\circ} \mathrm{C}\right)$ & \multicolumn{4}{|l|}{ Kidney } \\
\hline & & \multicolumn{2}{|c|}{$\begin{array}{l}\alpha \text {-L-iduronidase } \\
\text { (nmol/mg protein) }\end{array}$} & $\begin{array}{l}\text { B-galactosidase } \\
(\text { nmol/mg protein } / h)\end{array}$ & $\begin{array}{l}\text { Lactate dehydrogenase } \\
\text { (nmol NADH/mg protein } / \mathrm{min})\end{array}$ \\
\hline & & Per hour & Per 18 hours & & \\
\hline \multirow[t]{2}{*}{ Patient 1} & -30 & ND & ND & ND & ND \\
\hline & -70 & 0 & 0 & $75 \cdot 6$ & $98 \cdot 6$ \\
\hline \multirow{2}{*}{ Patient 2} & -30 & ND & ND & ND & ND \\
\hline & -70 & 0 & 0 & $70 \cdot 0$ & 170 \\
\hline Control 1 & $\begin{array}{l}-30 \\
-70\end{array}$ & ND & ND & ND & ND \\
\hline \multirow[t]{2}{*}{ Control 2} & $\begin{array}{l}-10 \\
-30\end{array}$ & $\begin{array}{l}2 \cdot 6 \\
\text { ND }\end{array}$ & $\begin{array}{l}12 \cdot 5 \\
\text { ND }\end{array}$ & $\begin{array}{l}410 \\
\text { ND }\end{array}$ & $\begin{array}{l}105 \\
\text { ND }\end{array}$ \\
\hline & -70 & $2 \cdot \overline{7}$ & $11 \cdot 6$ & 360 & 154 \\
\hline \multirow{2}{*}{ Control 3} & -30 & ND & ND & ND & ND \\
\hline & -70 & $2 \cdot 0$ & $12 \cdot 0$ & 283 & 165 \\
\hline \multirow[t]{2}{*}{ Control 4} & $\begin{array}{l}-30 \\
-70\end{array}$ & $\begin{array}{l}\text { ND } \\
2 \cdot 1\end{array}$ & $\begin{array}{l}\text { ND } \\
7.3\end{array}$ & ND & ND \\
\hline & -10 & $2 \cdot 1$ & & 336 & 152 \\
\hline
\end{tabular}

ND $=$ Not done. 
formalin and blocks were subsequently taken for light and electron microscopy. In patient 1 only tissue fixed in formalin was available and this was used for light and electron microscopy.

\section{Results}

\section{BIOCHEMICAL STUDIES}

We found no $\alpha$-L-iduronidase activity in any of the postmortem tissues (brain, liver, and kidney), although such activity was present in the control subjects' tissues which had been stored under the same conditions for similar periods of time. Tissue from patients with Hurler disease had lower activities than the control tissues of $\beta$-galactosidase, a reference lysosomal enzyme, but similar activities of lactate dehydrogenase a reference non-lysosomal enzyme. These results are shown in Tables 2 and 3.

We also found no significant $\alpha$-L-iduronidase activity in fibroblasts grown from superficial skin biopsies and the deeper subcutaneous tissues of either the transplant sites or a site (the upper arm) remote from the transplant site. These cells contained normal activities of the control $\beta$-galactosidase.

In the case of patient 1 the peripheral biopsies were taken from the upper arm (the site usually used for diagnostic biopsies) and the lower lumbar region; and the fourth and sixth transplant sites were sampled. In the case of patient 2 cells grown from a pretransplant biopsy and stored in liquid nitrogen were assayed simultaneously with the cells grown from the first, second, and third transplant sites. The $\beta$-galactosidase activities for control cells grown from two separate biopsies remote from the trans- plantation site in patient 1 were 312 and 223 $\mathrm{nmol} / \mathrm{mg}$ protein/h and those from the transplantation site were $155-305 \mathrm{nmol} / \mathrm{mg}$ protein $/ \mathrm{h}$. In patient 2 , the $\beta$-galactosidase values were: control cells $262 \mathrm{nmol} / \mathrm{mg}$ protein $/ \mathrm{h}$ and site biopsies 80 $262 \mathrm{nmol} / \mathrm{mg}$ protein $/ \mathrm{h}$. Reference data obtained on skin biopsies from 16 control subjects (10 children having diagnostic biopsies and six volunteers in whom there was no question of their having a lysosomal storage disease, were as follows: $\alpha$ L-iduronidase with 4-methylumbelliferyl iduronide substrate, $10 \cdot 7-34 \cdot 1 \mathrm{nmol} / \mathrm{mg}$ protein $/ \mathrm{h}$ (mean $=$ $18 \cdot 5, \mathrm{SEM}=1 \cdot 7, \mathrm{n}=16$ ) and $42 \cdot 2-64.4 \mathrm{nmol} / \mathrm{mg}$ protein $18 \mathrm{~h}($ mean $=55 \cdot 7, \mathrm{SEM}=1 \cdot 7, \mathrm{n}=16)$; the results with phenyliduronide were 276-1981 $\mathrm{nmol} / \mathrm{mg}$ protein $/ 18 \mathrm{~h}$ (mean $=1060, \mathrm{SEM}=142, \mathrm{n}$ $=16$ ). The reference data for $\beta$-galactosidase were: $310-699 \mathrm{nmol} / \mathrm{mg}$ protein $/ \mathrm{h}$ (mean $=470, \mathrm{SEM}=$ $30 \cdot 3, \mathrm{n}=15)$.

\section{STRUCTURAL STUDIES}

Histology. Although some sections showed an increase in connective tissue and the presence of $\stackrel{\infty}{\infty}$ some swollen, vacuolated cells, the routinely processed haematoxylin and eosin and azure A stained sections were not found to be satisfactory for assessing the degree of abnormal glycosaminoglycan (GAG) storage (Fig. 2 and 3).

\section{Histochemistry}

Necropsy tissues (Hurler disease-patients 1 and 2.) All the tissues examined showed some metachromatic staining which was taken as evidence of abnormal GAG storage. A piece of skin from a normal young adult member of staff showed no such

Table 3 Iduronidase, $\beta$-galactosidase and lactate dehydrogenase activity of brain (these determinations were all made on tissue stored at $-70^{\circ} \mathrm{C}$ )

\begin{tabular}{|c|c|c|c|c|c|}
\hline \multirow[t]{2}{*}{ Subject } & \multirow[t]{2}{*}{ Region of brain } & \multicolumn{2}{|c|}{$\begin{array}{l}\alpha \text {-L-iduronidase } \\
\text { (nmol/mg protein) }\end{array}$} & \multirow[t]{2}{*}{$\begin{array}{l}\text { B-galactosidase } \\
(\text { nmol/mg protein/h) }\end{array}$} & \multirow[t]{2}{*}{$\begin{array}{l}\text { Lactate dehydrogenase } \\
\text { (nmol NADH/mg protein/min) }\end{array}$} \\
\hline & & Per hour & Per 18 hours & & \\
\hline Patient 1 & $\begin{array}{l}\text { Frontal cortex } \\
\text { Occipital cortex } \\
\text { Temporal lobe } \\
\text { Basal ganglia } \\
\text { Cerebellum }\end{array}$ & $\begin{array}{l}0 \\
0 \\
0 \\
0 \\
0\end{array}$ & $\begin{array}{l}0 \\
0 \\
0 \\
0 \\
0\end{array}$ & $\begin{array}{l}20 \cdot 0 \\
10 \cdot 2 \\
43 \cdot 3 \\
16 \cdot 5 \\
52 \cdot 0\end{array}$ & $\begin{array}{l}93 \cdot 6 \\
98 \cdot 5 \\
83 \cdot 3 \\
84 \cdot 1 \\
82 \cdot 7\end{array}$ \\
\hline Patient 2 & $\begin{array}{l}\text { Frontal cortex } \\
\text { Basal ganglia } \\
\text { Cerebellum }\end{array}$ & $\begin{array}{l}0 \\
0 \\
0\end{array}$ & $\begin{array}{l}0 \\
0 \\
0\end{array}$ & $\begin{array}{r}11 \cdot 7 \\
11 \cdot 7 \\
4 \cdot 8\end{array}$ & $\begin{array}{c}147 \\
98 \cdot 3 \\
102\end{array}$ \\
\hline $\begin{array}{l}\text { Control 1 } \\
\text { ( } \$ 74 \text { yr) } \\
\text { Control } 2 \\
\text { ( } \$ 53 \text { yr) } \\
\text { Control } 3 \\
\text { (? sex } 79 \text { yr) } \\
\text { Control } 4 \\
\text { ( } \$ 60 \text { yr) }\end{array}$ & $\begin{array}{l}\text { Frontal cortex } \\
\text { Cerebellum } \\
\text { Frontal cortex } \\
\text { Cerebellum } \\
\text { Frontal cortex } \\
\text { Cerebellum } \\
\text { Frontal cortex } \\
\text { Cerebellum }\end{array}$ & $\begin{array}{l}N D \\
0.5 \\
0.5 \\
0.9 \\
0.5 \\
1.5 \\
0.6 \\
0.8\end{array}$ & $\begin{array}{l}N D \\
4 \cdot 4 \\
5 \cdot 0 \\
6 \cdot 8 \\
5 \cdot 2 \\
6 \cdot 1 \\
7 \cdot 0 \\
4 \cdot 4\end{array}$ & $\begin{array}{l}N D \\
50 \cdot 7 \\
30 \cdot 7 \\
31 \cdot 6 \\
55 \cdot 8 \\
28 \cdot 9 \\
46 \cdot 8 \\
24 \cdot 1\end{array}$ & $\begin{array}{c}N D \\
79.8 \\
248 \\
97 \cdot 7 \\
260 \\
95 \cdot 7 \\
264 \\
83.9\end{array}$ \\
\hline
\end{tabular}

ND $=$ not done. 


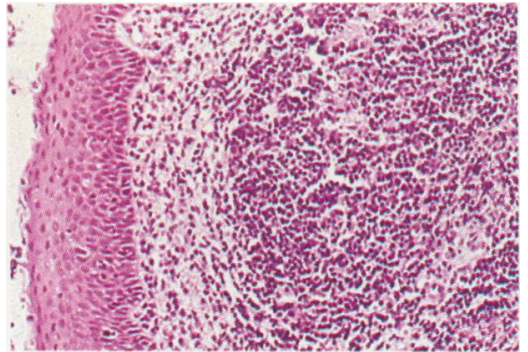

Fig. 2 Routinely processed paraffin section from tonsil of patient 4 (Hunter disease) reveals little pathological abnormality. Haematoxylin and eosin. Original magnification $\times 80$

staining. The results of the scoring for the degree of metachromasia are shown in Tables 4 and 5. Except for cartilage, the control sections, which had been pretreated with formol saline $(10 \% \mathrm{vol} / \mathrm{vol})$, showed no metachromasia and this is illustrated in the case of mitral valve in Figs. 4 and 5 . In many of the tissues there was a relative sparing of the parenchyma in comparison with collagenous connective tissue and this is illustrated in the myocardium (Fig. 6) and the brain (Fig. 7) where the metachromasia is most marked in perivascular connective tissue. The liver was an exception to this generalisation in that the hepatocytes and connective tissue were both heavily involved. In case 2 comparison of the fibroblast transplantation sites in the skin with other areas of skin shows there to be no reduction in metachromasia of the transplant sites (Figs. 8 and 9).

Fetal tissues (Hurler disease). As shown in Table 6, slight 'metachromasia was detected in skin, mitral valve, connective tissue around the spinal cord, the

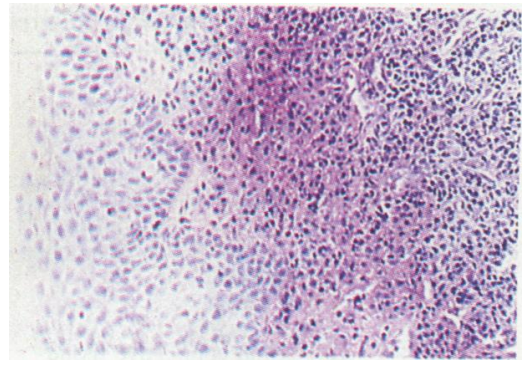

Fig. 3 Using Dorling's ${ }^{20}$ technique for demonstrating glycosaminoglycans, there is diffuse metachromasia in the tissue beneath the squamous epithelium in the tonsil of . patient 4 (Hunter disease). Dorling's ${ }^{20}$ Azure A. Original magnification $\times 80$

dura mater and the connective tissue of the spleen. Surgical specimens (Scheie disease, patient 3, Hunter disease, patient 4). Both the ligamentum flavum and the dura mater from patient 3 showed positive metachromasia between the collagen fibres although there was relatively little intracellular positivity. The tonsil from patient 4 showed considerable connective tissue metachromasia (Fig. 3) whereas the haematoxylin and eosin section from a comparable area reveals no notable abnormality (Fig. 2).

\section{Electron microscopy}

Necropsy tissues (Hurler disease, patients 1 and 2). Cells with their cytoplasm distended by multiple vacuoles (lysosomes) were widespread and the results of scoring for their presence are shown in Tables 5 and 6. Typical examples of such vacuolated cells are shown in Fig. 10 (patient 1, dura mater) and in Fig. 11 (patient 2, fibroblast transplantation site in skin).

Vacuoles containing striated membranous mater-

Table 4 Patient 1. Hurler disease-necropsy tissues

\begin{tabular}{llll}
\hline Tissue & & Metachromasia & Intracellular vacuoles \\
\hline Skin & Epidermis & - & ND \\
& Dermis & ++ & ND \\
Apeart & Mitral valve & ++ & ND \\
Brain & Frontal lobe, neurones and glia & +++ & ++ \\
& Frontal lobe, connective tissue & + & + \\
& Cerebellum, neurones and glia & ++ & ND \\
& Cerebellum, connective tissue & + & ND \\
& Leptomeninges & ++ & ++ \\
Eye & Dura mater & ++ & ++ \\
& Conjunctival epithelium & ND & ++ \\
& Conjunctival connective tissue & ND & ++ \\
& Corneal stroma & ND & ++ \\
& Retina & ND & ++ \\
Liver & Iris & ND & ++ \\
& Filtration angle & ++ & + \\
\hline
\end{tabular}

* = Zebra bodies

$\mathrm{ND}=$ not done. 
Table 5 Patient 2. Hurler disease-necropsy tissues

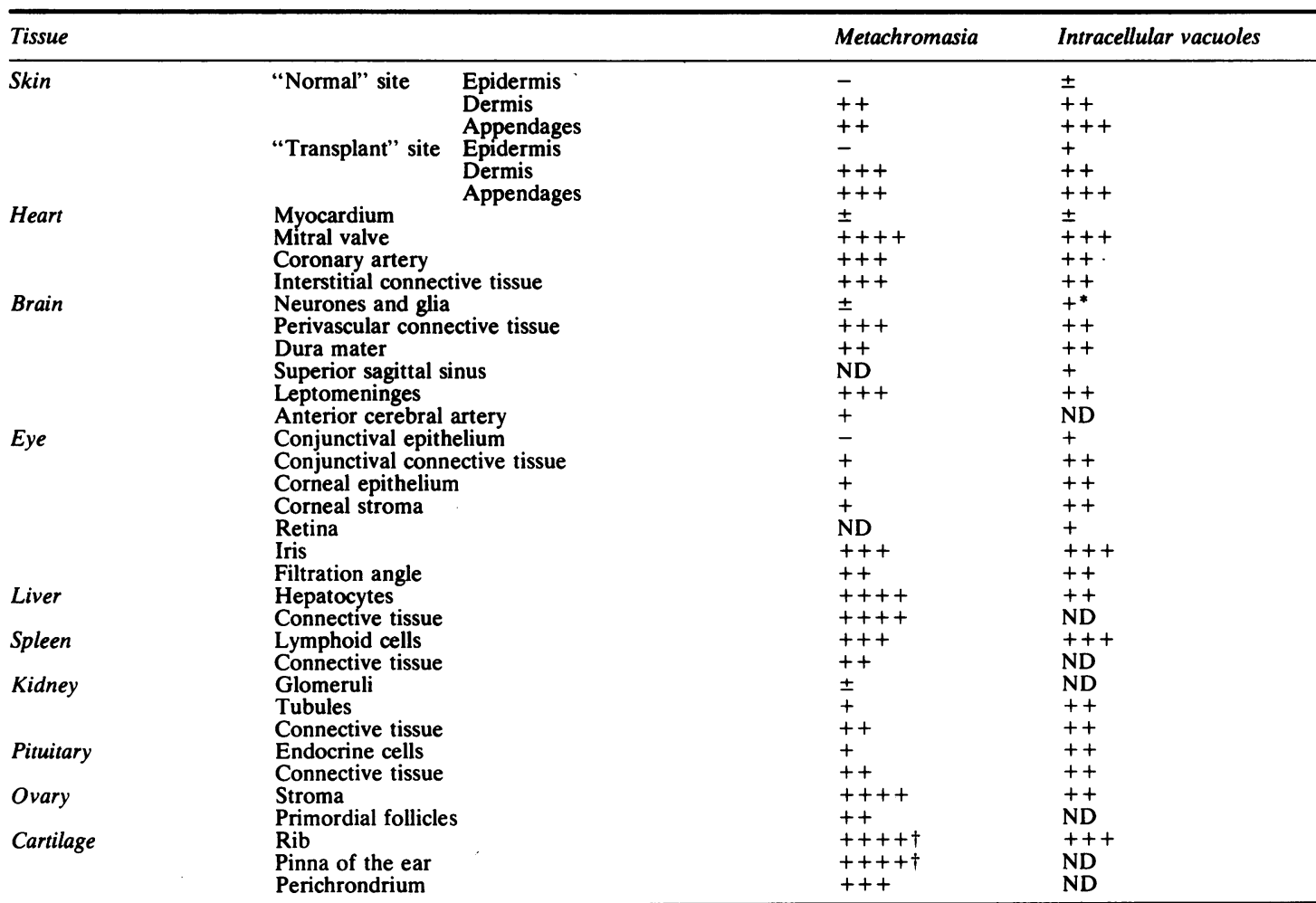

*Zebra bodies.

†Formalin-treated controls also showed marked matrix metachromasia but EM showed normal appearance of cartilage matrix. $\mathrm{ND}=$ not done.

ial (Zebra bodies) were seen in occasional cells in the brain in patient 2 (Fig. 12) and in the retina of patient 1.

Fetal tissues (Hurler disease). As shown in Table 7 some cells containing a few vacuoles were identified and in the spinal cord occasional cells with Zebra body inclusions were seen.

Surgical specimens (Scheie disease, patient 3; Hunter disease, patient 4). Nearly all the cells seen in the tissue from ligamentum flavum and dura mater were vacuolated and many of them also contained laminated membranous bodies resembling the Zebra bodies described above (Table 7 and Fig. 13).

Cells with vacuolated cytoplasm were widespread in the tonsil from patient 4. Although ultrastructural features could not be used to identify the nature of these cells because the cytoplasmic organelles were replaced by the distended lysosomes, it is assumed that they are either of fibroblast or macrophage derivation since the lymphoid cells appeared relatively unaffected (Fig. 14)

\section{Discussion}

The present findings show that as with the clinical and in vivo biochemical results, ${ }^{621} 22$ there was no pathological or postmortem biochemical evidence that the fibroblast transplantation had modified the outcome in patients with Hurler disease. If the transplanted cells had been producing a therapeuti- $\sigma$ cally useful amount of enzyme, which was being dis- $N$ tributed to the recipient's cells one might have $\mathrm{W}_{\mathrm{N}}$ expected to have seen some evidence of local clear- 0 ing of glycosaminoglycan deposits. The interstitial glycosaminoglycans as seen histochemically were $\stackrel{\odot}{\odot}$ plentiful around the transplantation sites (Fig. 9) $\stackrel{\mathscr{D}}{?}$ suggesting that even the activity of $\alpha$-L-iduronidase 0 being produced locally was insufficient to affect the GAG accumulation.

Intracellular glycosaminoglycans can be cleared $\stackrel{\frac{\pi}{\infty}}{\circ}$ from fibroblasts by exogenously supplied $\alpha$-Liduronidase as in the cross correction studies described here. Olsen and his colleagues $^{23}$ have 


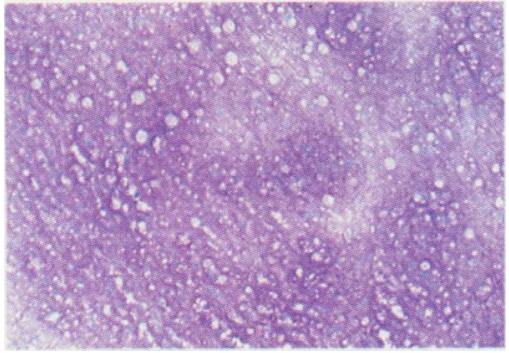

Fig. 4

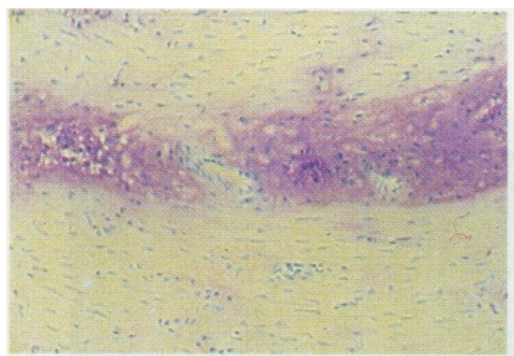

Fig. 6

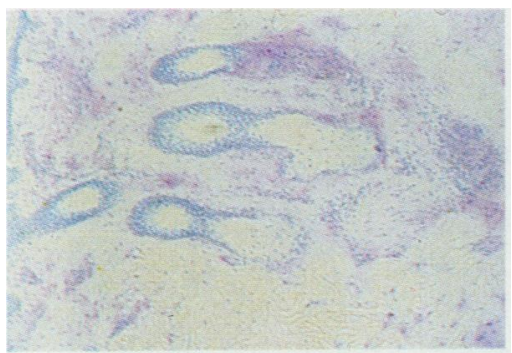

Fig. 8

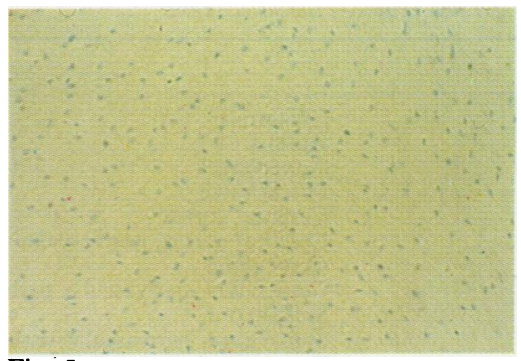

Fig. 5

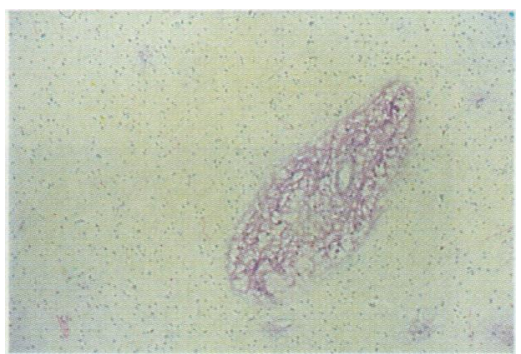

Fig. 7

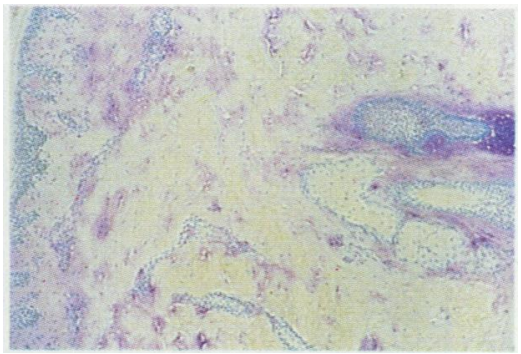

Fig. 9

Figs. 4-9 Tissues from patient 2 (Hurler disease) stained by Dorling's ${ }^{20}$ Azure A technique. Original magnifications are indicated. Fig. 4 Section from mitral valve shows marked interstitial metachromasia. $\times 80$; Fig. 5 Mitral valve formalin treated control section shows no metachromasia. $\times 80$; Fig. 6 Section from myocardium shows that metachromasia is mainly confined to the perivascular connective tissue with the adjacent myocardial fibres (top and bottom) being largely unstained. $\times 80 ;$ Fig. 7 Section from frontal lobe of brain shows metachromasia largely confined to the perivascular area which is dilated and contains many vacuolated cells. The adjacent brain tissue shows very little staining. $\times 32 ;$ Fig. 8 Section from area of "normal" skin shows patchy dermal metachromasia which is more dense around skin appendages. $\times 32$; Fig. 9 Section from skin fibroblast transplant site shows no diminution of metachromasia compared with the "normal" skin in Fig. 8. $\times 32$.

shown the direct transfer of a lysosomal enzyme [ $\beta$-glucuronidase (EC 3.2.1.31)] from lymphoid cells to fibroblasts deficient in the enzyme. The transfer of enzyme between fibroblasts and mouse peritoneal macrophages has also been demonstrated. ${ }^{24}$ These processes may be the same as or related to that described as metabolic co-operation ${ }^{25}$ and show that the possibility of enzyme replacement therapy by cell transplantation need not be limited by the receptor mediated pinocytosis described by other workers. ${ }^{2627}$ Full correction, both chemical and ultrastructural, has been demonstrated in cultured fibroblasts from patients with Hunter disease after incubation with exogenous $\alpha$-L-idurono2-sulphate sulphatase. ${ }^{28}$ However, long-term storage products in vivo may not be accessible to degradation: for example, overloaded lysosomes might not fuse normally with pinocytic vesicles containing exogenously supplied enzyme.

There was no evidence that the recipients had 
Table 620 wk-fetus-Hurler disease

\begin{tabular}{llll}
\hline Tissue & & Metachromasia & Intracellular vacuoles \\
\hline Skin & Epidermis & - & - \\
& Dermis & + & + \\
Heart & Appendages & \pm & - \\
Brain & Mitral valve & + & + \\
& Cerebral cortex & - & - \\
& Cerebral cortex, perivascular tissue & - & ND \\
& Cerebellum & - & $-*$ \\
& Cerebellum, perivascular tissue & - & ND \\
Spinal cord & Spinal cord, perivascular tissue & + & + \\
& Dura mater & - & \pm \\
& Lymphoid and haemopoietic cells & + & + \\
\hline
\end{tabular}

*Zebra bodies.

ND $=$ not done.

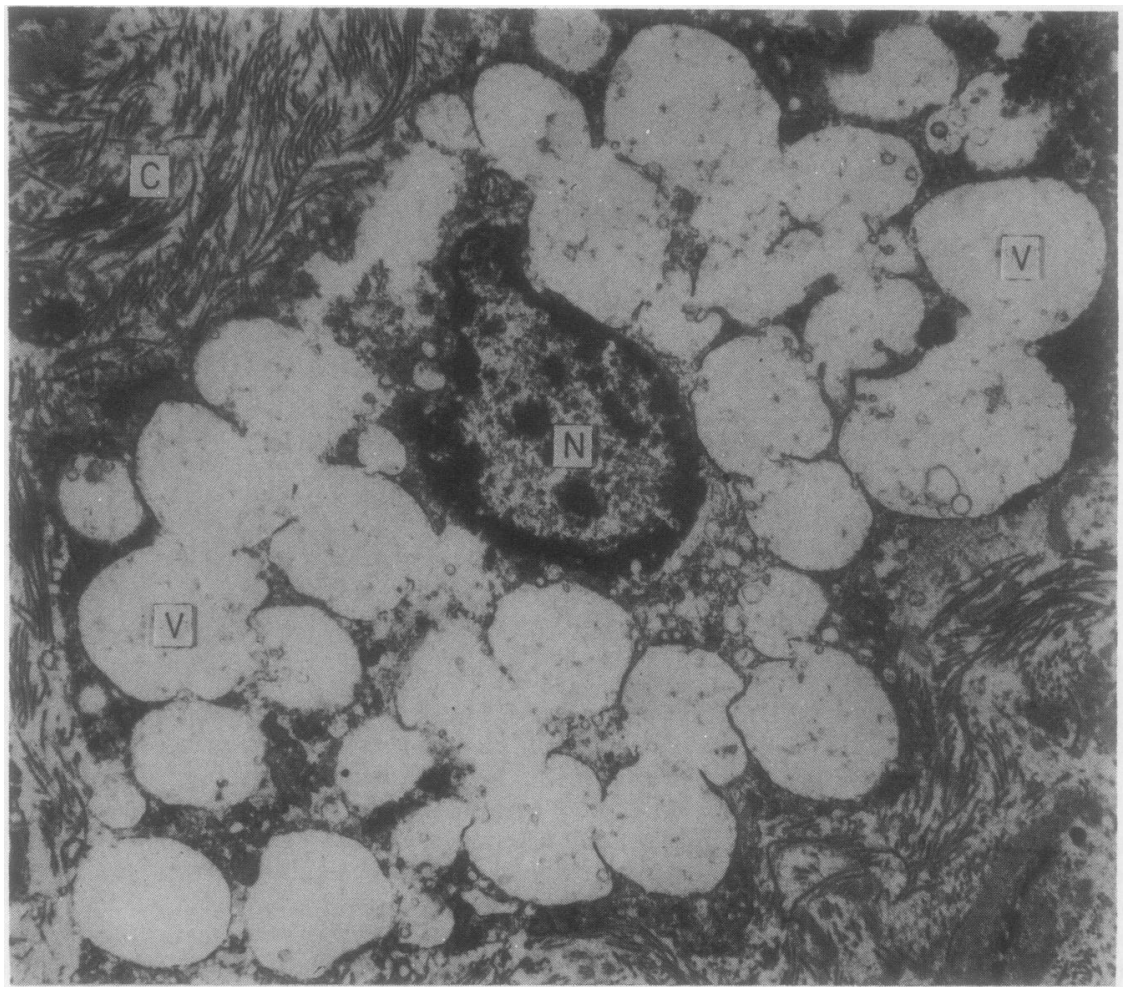

Fig. 10 Electron micrograph of a typical vacuolated cell in the dura mater of patient 1 (Hurler disease). $N=$ nucleus, $V=$ vacuoles, $C=$ collagen fibres. $\times 6350$

mounted an immunological attack on the transplanted fibroblasts as judged by failure to produce either complement-dependent cytotoxic antibodies, antibody-dependent cellular cytotoxicity or cytotoxic $T$ cell activity. ${ }^{6}$ Therefore the large amount of interstitial glycosaminoglycans at the transplantation sites suggests that the therapeutic failure was due to a failure of the graft to produce a useful amount of enzyme rather than to failure of $\stackrel{\mathscr{D}}{\mathscr{D}}$ either endocytic carrier cells (polymorphonuclear leucocytes and macrophages) to distribute it or of the target cells to make use of it. The fact that donor $\vec{D}$ cells grew well when they were recultured in vitro, $\frac{\mathbb{D}}{\mathbb{D}}$ shows that they were viable.

It is possible that the failure to achieve either an appreciable level of enzyme activity or evidence of $\delta$ 


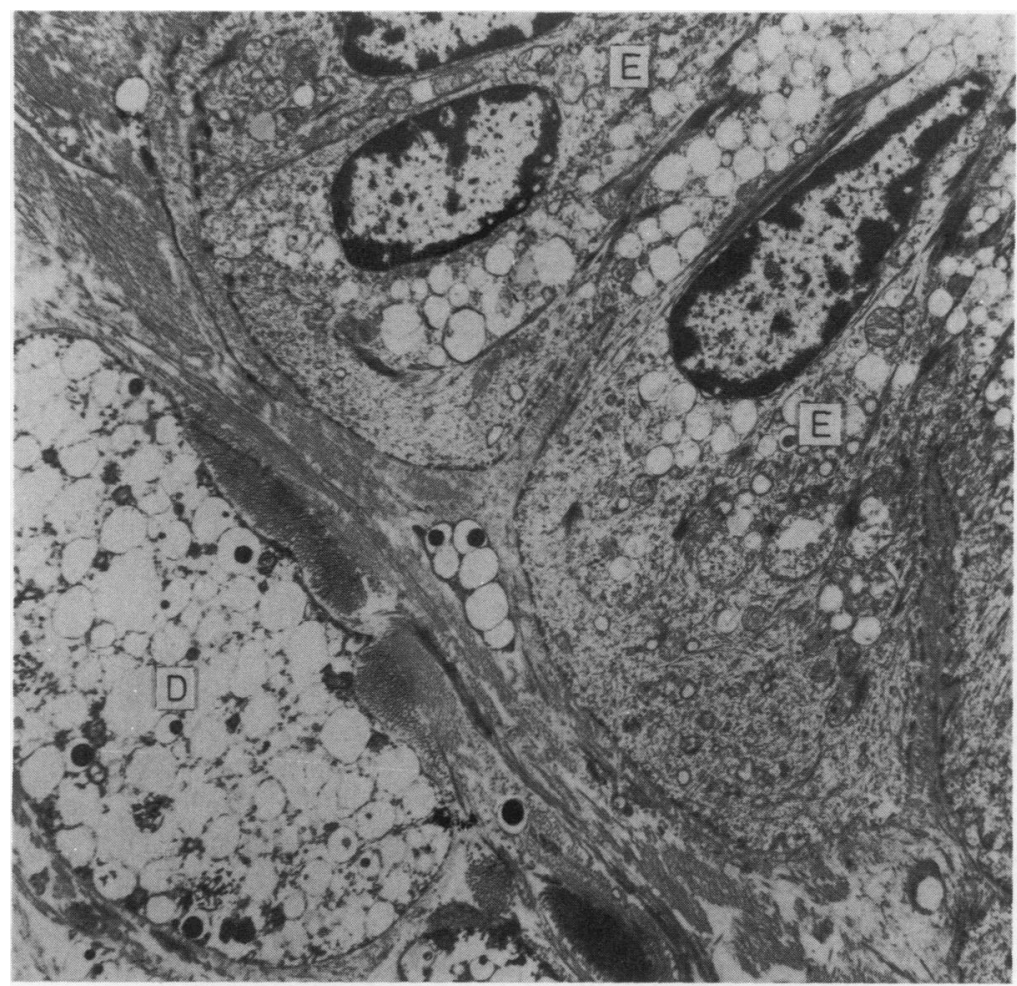

Fig. 11 Electron micrograph from fibroblast transplant site in skin of patient 2 (Hurler disease). Vacuoles are seen in the epithelial hair follicle cells $(E)$ and in the adjacent dermal cells (D). $\times 5400$

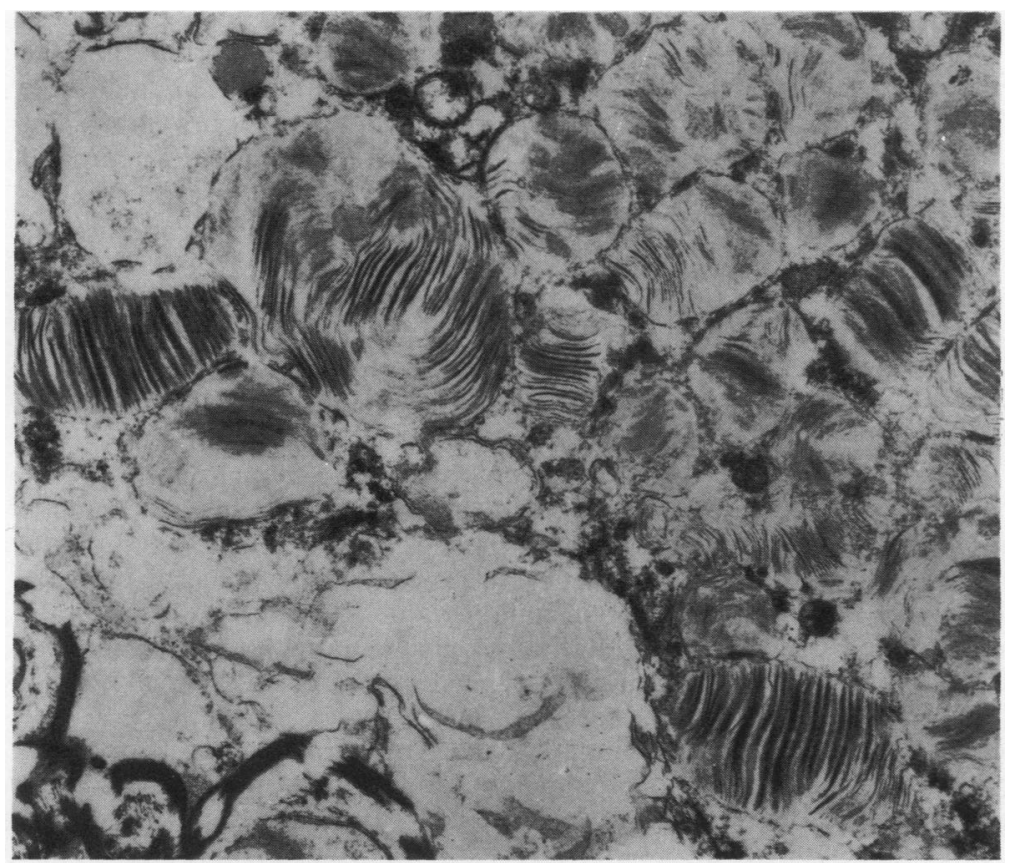

Fig. 12 Part of a neurone in the basal ganglia of patient 2 (Hurler disease) showing laminated "Zebra body" inclusions. $\times 13090$ 


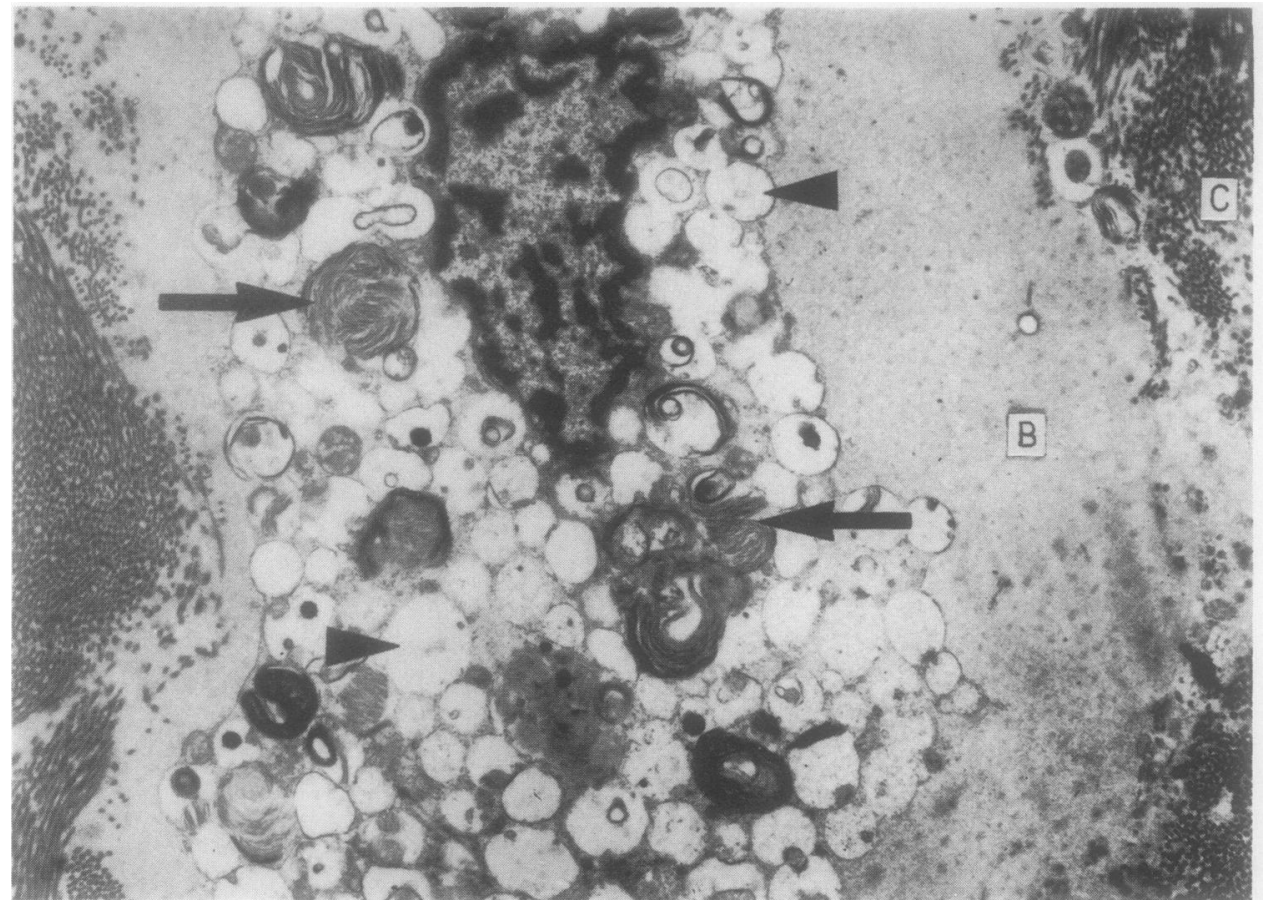

Fig. 13 A cell in the dura mater of patient 3 (Scheie disease) showing a combination of almost clear vacuoles (arrowheads) and membranous myelinoid structures (arrows) somewhat resembling the Zebra. bodies shown in Fig. 12. There is an amorphous band $(B)$ separating the cell from the adjacent collagen fibres $(C) \times 7190$

Table 7 Patients 3 (Scheie disease) and 4 (Hunter disease) surgical specimens

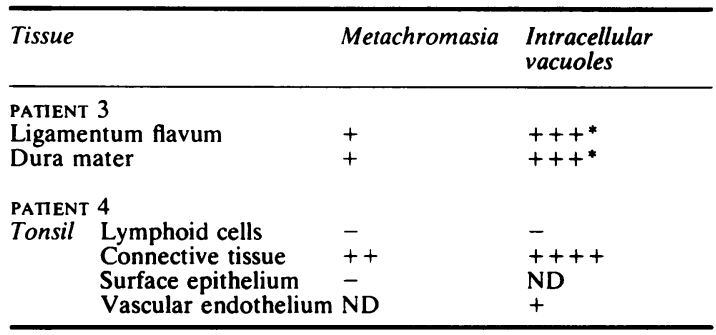

*Myelinoid figures resembling Zebra bodies.

$\mathrm{ND}=$ not done.

clinical, or pathological improvement in the patients when they were transplanted may have been due to the relatively small number of cells [about $10^{9}-10^{10}$ per transplant] ${ }^{6}$ that we were able to introduce: Hobbs and his colleagues ${ }^{29}$ achieved heterozygote activities of $\alpha$-L-iduronidase in peripheral blood leucocytes after heterozygote bone marrow transplantation in a patient with Hurler disease. This procedure introduces a replicating cell population, which supplies about $200-300 \mathrm{~g}$ of potentially enzyme transporting and distributing cells (leucocytes) per day. These authors reported that the hepatosplenomegaly and corneal clouding were reduced but the long-term therapeutic value of this procedure, particularly with respect to the neurological involvement, remains to be assessed. The evidence of organ involvement by the twentieth week of gestation means that enzyme replacement with a source of replicating enzyme containing and distributing cells should begin either before or immediately after birth.

The postmortem, histological and ultrastructural appearances in the mucopolysaccharidoses have been extensively studied although some more detailed necropsy studies ${ }^{30}{ }^{31}$ antedated the precise delineation of these diseases on the basis of the enzyme deficiencies. Routine histological preparations are of limited value in this group of disorders due to elution of glycosaminoglycans by aqueous solutions and special measures are needed to produce reliable histochemical staining of the glycosaminoglycans..$^{20}$ Electron microscopy is a sensitive technique but only shows the presence of distended vacuoles from which much of the glycosaminoglycans has been dissolved (Figs. 10 and 


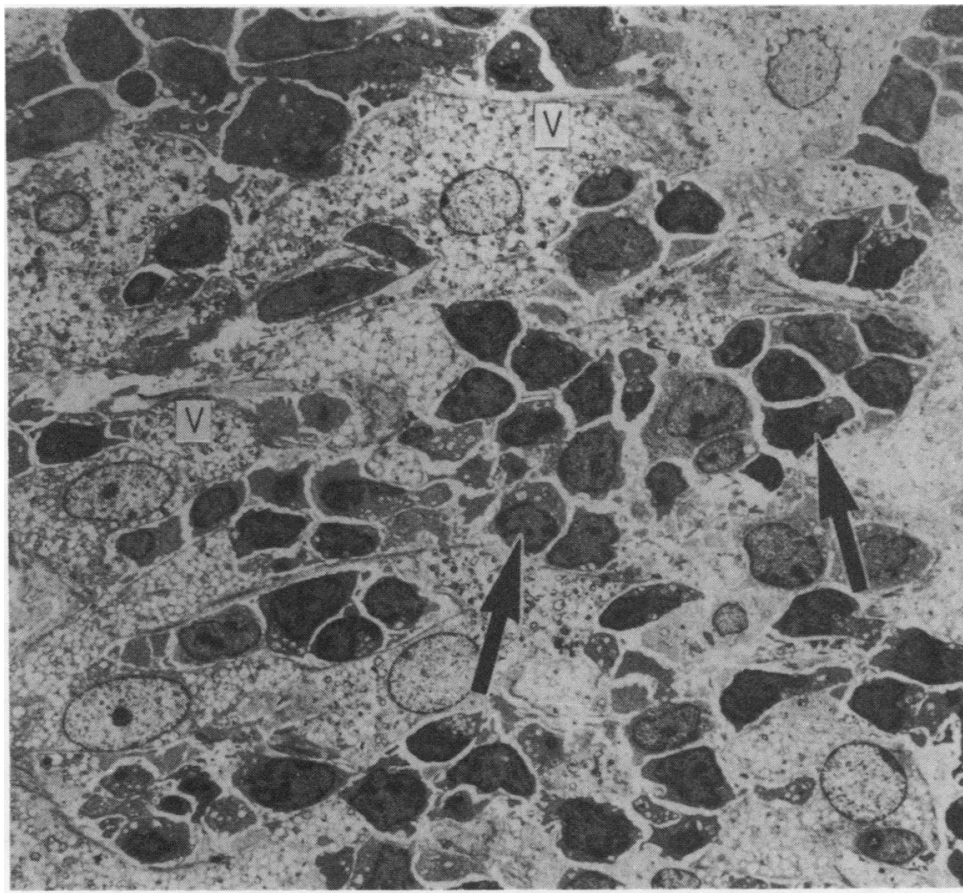

Fig. 14 Electron micrograph from area of tonsil of patient 4 (Scheie disease) corresponding to the metachromasia shown in Fig. 3. Cells with copious vacuolated cytoplasm $(V)$ are seen interspersed with relatively unaffected lymphoid cells (arrows). $\times$ 1360

11). It does, however, show the ultrastructure of the lysosomes in situations where the abnormal storage of glycosaminoglycans has produced a secondary lysosomal metabolic lesion affecting the degradation of gangliosides and which produces the characteristic lamellated membranous inclusions (Zebra bodies) in brain cells Fig. 12..$^{32-37}$ Electron microscopy is not able to detect extracellular glycosaminoglycans, and the results for the intracellularly stored material are difficult to measure on small specimens. Its sensitivity makes it particularly suitable for the investigation of fetal material. ${ }^{38} 39$ The present work illustrates the advantages of using a dual approach to the structural studies. The histochemical method, designed to reduce the amount of diffusion of glycosaminoglycans, is valuable because of its ability to assess the extent of extracellular as well as intracellular accumulation of glycosaminoglycans. Electron microscopy was also used because of its greater sensitivity for the detection of intracellular changes. Although the mucopolysaccharidoses are due to specific single enzyme defects the variability of expression between patients makes the accurate assessment of the pathological changes in different tissues particularly important. The results of the scoring of the histochemistry and electron microscopy findings generally paralleled one another (Tables 4-7).

Skin biopsies are commonly used for dermatolog- ical diagnosis as well as a source of cultured fibroblasts for biochemical diagnosis of the inborn errors of metabolism. As in previous reports ${ }^{40-44}$ we found that the dermal cells and the skin appendages (hair follicles, sebaceous and sweat glands) are most severely affected with relative sparing of the surface epidermis (Figs. 8 and 9) although more extensive involvement of the epidermis has been reported over the fingers. ${ }^{45}$ As with the histochemical results no significant differences could be detected at the transplant sites compared with other areas of skin by EM examination.

We made a particularly close study of the eye because blindness may be multifactorial in the mucopolysaccharidoses. ${ }^{46} 47$ Both patients 1 and 2 had corneal clouding and patient 1 also had an episode of acute glaucoma necessitating a trabeculectomy to relieve raised intraocular pressure. ${ }^{48}$ In both these children evidence of abnormal glycosaminoglycan storage was found in the conjunctiva, cornea, retina, iris and the filtration angle, indicating that probably all areas of the eye may be susceptible to damage in Hurler disease.

Within the brain, metachromasia was irregular and slight in the neural tissue itself although the perivascular regions (Fig. 7), connective tissue and meninges were severely affected. This correlated with the presence of few vacuoles in the neurones compared with many vacuolated cells around the 
blood vessels and in the meninges (Figs. 10 and 13). This also agrees with the description of "foam cells" in the Virchow-Robin spaces ${ }^{49}$ and greatly dilated periadventitial spaces ${ }^{35}$ which Watts et al ${ }^{9}$ correlated with the areas of cavitation and pitting visible at necropsy around blood vessels on the cut surface of the white matter in Hurler disease ${ }^{50}$ and with the low density lesions seen in the white matter on computed tomography (CT). ${ }^{9}$ Such pitted areas were not seen in either of the present patients at postmortem although white matter low attenuation lesions had been seen in both patients on CT. Reduced absorption of $x$-rays producing the low density lesions on CT is attributed to the increased fluid content of the perivascular mucopolysaccharide rich lesions, the latter were well demonstrated microscopically (Fig. 7) but were presumably not large enough to be demonstrated macroscopically as pitted areas.

Laminated Zebra body lesions were seen in the brain of patient 2 (Fig. 2) and the spinal cord of the fetus. These have been ascribed to a secondary disorder of sphingolipid degradation. ${ }^{3751}$ Patient 1 who became blind in association with acute glaucoma ${ }^{48}$ but who had no recovery of vision after bilateral trabeculectomies showed Zebra body lesions in the ganglion cells of the retina. Similar lamellated bodies have been found in the ganglion cells of the rectum, ${ }^{52}$ in Schwann cells and in a Merkel cell of the skin. ${ }^{41}$

The extensive involvement of the interstitial tissues of the heart and of the mitral valve correlates with the findings during life. The echocardiogram results in patient 2 suggested hypertrophic cardiomyopathy (HOCM). The characteristic histological features of HOCM were not found at postmortem and we ascribe the thickening of the left ventricle to deposition of interstitial glycosaminoglycans. The walls of the coronary arteries were also thickened in both cases although neither patient had symptoms of coronary insufficiency probably because they were both chair-bound terminally.

Metachromasia is difficult to interpret in cartilage because the control formalin treated sections are also positive due to metachromatic staining of the chondroitin sulphates. However, the chondrocytes showed marked vacuolation on electron microscopy, as has also been described for Morquio disease (MPS IV). ${ }^{53}$

The need for a spinal decompression in patient 3 (Scheie disease) presented an opportunity to examine freshly fixed operation specimens of ligamentum flavum and dura mater. The patient was 22 years old and therefore considerably older than the children with Hurler disease. Although the cells in these tissues showed similar features to the Hurler cells, the vacuoles contained more membranous myelinoid material so that they resembled the neuronal Zebra bodies (Figs. 12 and 13). With the passage of time, the effects of secondary inhibition of enzymes may become similar to those seen in neurones. The results of the metachromasia study in this case also differed somewhat from those of the children with Hurler disease because, although the background connective tissue stained strongly, the intracellular staining was faint. This may represent greater GAG diffusion out of the cells, and in the dura this may be correlated with the presence of a distinct amorphous zone separating the cells from the adjacent collagen fibres (Fig. 13).

Our findings in the fetus at 20 wk gestation agree with previous results ${ }^{38}{ }^{39}$ showing that there is early glycosaminoglycan accumulation in some tissues. The nervous system involvement at this early stage may well limit the scope for enzyme replacement therapy.

We are pleased to acknowledge our indebtedness to Dr G Slavin, Dr EM Thompson, Dr I Jeffrey and Dr B Gostelow for their help with the postmortems, to Mr J Dorling, Mrs J Webb and Mr C Sheldon for their technical assistance.

Note added in proof: Since this paper was completed a second affected fetus $(20 \mathrm{wk})$ from the mother of $\bar{\partial}$ patient 2 has been examined. Similar vacuolation was seen in the following: mitral valve, dura mater, $\stackrel{\mathbb{Q}}{\varrho}$ cornea, vasular endothelial cells in the spinal cord. $\overrightarrow{\vec{P}}$ There was no vacuolation in the frontal lobe and $\frac{0}{3}$ spinal cord neurones.

\section{References}

${ }^{1}$ Van Hoof F. Mucopolysaccharidoses and mucolipidoses. J Clin Pathol 1974;Suppl8:1-11.

${ }^{2}$ Kresse H, Pashke G, Von Figura K, Gilberg W, Fuchs W. Sanfilippo disease type D: Deficiency of $\mathrm{N}$-acetylglucosamine-6-sulphate sulphatase required for heparan sulphate degradation. Proc Natl Acad Sci USA ․ㅡ․ 1980;77:6822-6.

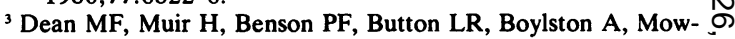
bray J. Enzyme replacement therapy by fibroblast transplanta- $N$ tion in a case of Hunter syndrome. Nature 1976;261:323-5.

${ }^{4}$ Dean MF, Stevens RL, Muir H, et al. Enzyme replacement $\omega$ therapy by fibroblast transplantation. Long-term biochemical $\sigma$ study in three cases of Hunter's syndrome. J Clin Invest 1979;63:138-46.

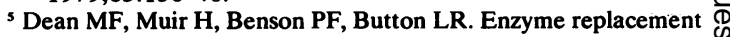
therapy by transplantation of HLA-compatible fibroblasts in ? Sanfilippo A syndrome. Pediatr Res 1981;15:959-63.

- Gibbs DA Spellacy.E. Tompkins R, Watts RWE, Mowbray J A clinical trial of fibroblast transplantation for the treatment of $\frac{\vec{D}}{\mathbb{D}}$ mucopolysaccharidoses. J Inher Metab Dis 1983 (in press):

7 Jeanloz RW. The nomenclature of mucopolysaccharidoses. Arthritis Rheum 1960;3:233-7.

${ }^{8}$ McKusick VA, Neufeld E, Kelley TE. The mucopolysaccharide

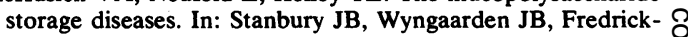


son DS, eds. The metabolic basis of inherited disease. 4th ed New York: McGraw-Hill, 1978.

9 Watts RWE, Spellacy E, Kendall BE, du Boulay G, Gibbs DA. Computed tomography studies on patients with mucopolysaccharidoses. Neuroradiology 1981;21:9-23.

${ }^{10}$ Gibbs DA, Spellacy E, Roberts A, Watts RWE. The treatment of lysosomal storage diseases by fibroblast transplantation: some preliminary observations. Birth defects 1980;16:457-74.

" Niermeijer MF, Halley D, Sachs E, Tichelaar-Klepper C, Garrer KL. Transport and storage of amniotic fluid samples for prenatal diagnosis of metabolic diseases. Humangenetik 1973;20:175-8.

${ }^{12}$ Hall CW, Neufeld EF. $\alpha$-L-iduronidase activity in cultured skin fibroblasts and amniotic fluid cells. Arch Biochem Biophys 1973;158:817-21.

${ }^{13}$ Cantz M, Kresse H, Barton RW, Neufeld EF. Corrective factors for inborn errors of mucopolysaccharide metabolism. Methods Enzymol 1972;28:884-97.

${ }^{14}$ Spellacy E, Gibbs DA, Watts RWE. A newly recognised syndrome of connective tissue dysplasia in siblings (previously described as a variant of Morquio disease). $Q J$ Med 1981;50:377-415.

${ }^{15}$ Rome LH, Weismann B, Neufeld EF. Direct demonstration of binding of a lysosomal enzyme, $\alpha$-L-iduronidase, to receptors on cultured fibroblasts. Proc Natl Acad Sci USA 1979;76:2331-4.

${ }^{16}$ Gibbs DA, Watts RWE. The identification of the enzymes that catalyse the oxidation of glyoxylate to oxalate in the 100,000 $\times g$ supernatant fraction of human hyperoxaluric and control liver and heart tissue. Clin Sci 1973;44:227-41.

${ }^{17}$ Lowry GH, Rosebrough NJ, Farr AL, Randall RJ. Protein measurement with a Folin phenol reagent. J Biol Chem 1951;193:265-75.

${ }^{18}$ Pennock CA. A review and selection of simple laboratory methods used for the study of glycosaminoglycan excretion and the diagnosis of the mucopolysaccharidoses. J Clin Pathol 1976;29:111-23.

${ }^{19}$ Humbel R, Chamoles NA. Sequential thin layer chromatography of urinary acidic glycosaminoglycans. Clin Chim Acta 1972;40:290-3.

${ }^{20}$ Dorling J. Localisation of sulphated glycosaminoglycans in the mucopolysaccharidoses by a simple technique using cryostat sections. J Clin Pathol 1980;33:897-8.

${ }^{21}$ Gibbs DA. Fibroblast transplantation in the lysosomal storage diseases. In: Crawfurd M d'A, Gibbs DA, Watts RWE eds, Advances in the treatment of inborn errors of metabolism. Chichester: John Wiley \& Sons 1982.

${ }^{22}$ Spellacy E. Assessment of clinical response to therapeutic programmes. In: Crawfurd M d'A, Gibbs DA, Watts RWE, eds, Advances in the treatment of inborn errors of metabolism. Chichester: John Wiley \& Sons 1982

${ }^{23}$ Olson I, Dean MF, Harris G, Muir H. Direct transfer of a lysosomal enzyme from lymphoid cells to deficient fibroblasts. Nature 1981;291:244-7.

${ }^{24}$ Dean MF, Diment S, Olson I, Muir H. Future prospects for cell transplantation. In: Crawfurd M d' A, Gibbs DA, Watts RWE, eds, Advances in the treatment of inborn errors of metabolism. Chichester: John Wiley \& Sons 1982.

${ }^{25}$ Subak Sharpe JH. Metabolic co-operation between cells. In: Wolstenholme GEW, Knight J, eds, Ciba Foundation symposium on homeostatic regulators. London: J \& A Churchill, 1969.

${ }^{26}$ Neufeld EF. Recognition and processing of lysosomal enzymes in cultured fibroblasts. In: Callahan JW, Lowden JA, eds, Lysosomes and lysosomal storage diseases. New York: Raven Press, 1981.

${ }^{27}$ Sly WS, Natowicz M, Gonzalez-Noriega A, Grubb JH, Fischer HD. The role of the mannose-6-phosphate recognition marker and its receptor in the uptake and intracellular transport of lysosomal enzymes. In: Callahan JW, Lowden JA, eds, Lyso- somes and lysosomal storage diseases. New York: Raven Press, 1981.

${ }^{28}$ Eliahu R, Sekeles E, Cohen R, Bach G. The correction of Hunter fibroblasts by exogenous iduronate sulfate sulfatase; biochemical and ultrastructural studies. Am J Hum Genet 1981;33:576-83.

${ }^{29}$ Hobbs, JR, Hugh-Jones K, Barrett AJ et al. Reversal of clinical features of Hurler's disease and biochemical improvement after treatment by bone-marrow transplantation. Lancet $1981 ;$ ii:709-12.

${ }^{30}$ Dawson IMP. The histology and histochemistry of gargoylism. $J$ Pathol Bacteriol 1954;67:587-604.

${ }^{31}$ Bishton RL, Norman RM, Tingey A. The pathology and chemistry of a case of gargoylism. J Clin Pathol 1956;9:305-15.

${ }^{32}$ Loeb H, Jonniaux G, Resibois A et al. Biochemical and ultrastructural studies in Hurler's syndrome. $J$ Pediatr 1968;73:860-74.

${ }^{33}$ Doshi R, Sandry SA, Churchill AW, Brownell B. The cerebellum in mucopolysaccharidoses. A histological, histochemical and ultrastructural study. J Neurol Neurosurg Psychiatry 1974;37:1133-8.

${ }^{34}$ Dekaban AS, Constantopoulos G, Herman MM, Steusing JK. Mucopolysaccharidosis type V (Scheie syndrome). A PM study by multidisciplinary techniques with emphasis on the brain. Arch Pathol Lab Med 1976;100:237-45.

${ }^{35}$ Dekaban AS, Constantopoulos G. Mucopolysaccharidosis types I, II, IIIA and V Pathological and biochemical abnormalities in the neural and mesenchymal elements of the brain. Acta Neuropathol (Berl) 1977;39:1-7.

${ }^{30}$ Kriel RL, Hauser A, Sung JH, Posalaky Z. Neuroanatomical and EEG correlations in Sanfilippo A syndrome. Arch Neurol 1978;35:838-43.

${ }^{37}$ Hadfield MG, Chatak NR, Nakoneczna I, et al. Pathological findings in mucopolysaccharidosis type IIIB. Arch Neurol 1980;37:645-50.

${ }^{38}$ Crawfurd M d'A, Dean MF, Hunt DM, et al. Early prenatal diagnosis of Hurler's syndrome with termination of pregnancy and confirmatory findings on the foetus. J Med Genet 1973;10:144-53.

${ }^{39}$ Hug G. Pre- and post-natal pathology, enzyme treatment and unresolved issues in five lysosomal disorders. Pharmacol Rev 1979;30:565-91.

${ }^{40}$ Kenyon KR, Quigley HA, Hussels IE, Wyllie RG, Goldberg MF. The systemic mucopolysaccharidoses. Ultrastructural and histochemical studies of conjunctiva and skin. Am J Ophthalmol 1972;73:811-33.

${ }^{4}$ Belcher RW. Ultrastructure of the skin in the genetic MPS. Arch Pathol 1972;94:511-8.

42 Belcher RW. Ultrastructure and function of eccrine glands in the MPS. Arch Pathol 1973;96:339-41.

${ }^{43}$ Spicer SS, Garvin AJ, Wohltmann HJ, Simson JAV. The ultrastructure of the skin in patients with MPS. Lab Invest 1974;31:488-502.

44 Spicer SS, Garvin AJ, Simson JAV, Wertelecki V. Cytochemistry of the skin in patients with MPS. Histochem J 1978;10:13750.

${ }^{45}$ Hambrick GW, Scheie HG. Studies on the skin in Hurler's syndrome. Arch Dermatol 1962;85:455-71.

${ }^{46}$ Francois J. Ocular manifestations of the mucopolysaccharidoses. Ophthalmologica 1974;169:345-61.

${ }^{47}$ Cotlier E. Corneal cloudiness and retinitis pigmentosa in the MPS. $N$ Engl J Med 1975;292:812.

${ }^{48}$ Spellacy E, Kennerley Bankes JL, Crow J, et al. Glaucoma in a case of Hurler disease. Br J Ophthalmol 1980;64:773-78.

49 Winters PR, Harrod MJ, Molenich-Heetred SA, Kirkpatrick J, Rosenberg J. $\alpha$-L-iduronidase deficiency and possible HurlerScheie genetic compound: Clinical, pathological and biochemical findings. Neurology 1976;26:1003-7.

${ }^{50}$ Crome L, Stern J. Pathology of mental retardation. 4th ed. Edinburgh and London: Churchill-Livingstone, 1972. 
51 Kint TA, Dacremont G, Carton D, Orye E, Hooft C. Mucopolysaccharidosis: secondarily induced abnormal distribution of lysosomal isoenzymes. Science 1973;181:352-4.

s2 Elsner B. Ultrastructure of the rectal wall in Hunter's syndrome. Gastroenterology 1970;58:856-62.

${ }^{53}$ Maynard JA, Cooper RR, Ponseti IV. Morquio's disease (MPS
IV) ultrastructure of epiphyseal plates. Lab Invest 1973;28:194-205.

Requests for reprints to: Dr RWE Watts, Division of Inherited Metabolic Diseases, Clinical Research Centre, Watford Road, Harrow, Middlesex, HA1 3UJ England. 